\title{
Eutrophication of the Mastník bay of the Slapy Reservoir, Czechia
}

\author{
Luboš Mrkva*, Bohumír Janský, Miroslav Šobr
}

Department of Physical Geography and Geoecology, Faculty of Science, Charles University, Czechia

* Corresponding author: mrkval@natur.cuni.cz

\begin{abstract}
This article investigates the changes in water quality in the Mastník bay, a part of the Slapy Reservoir located at the Vltava River, during the 2015-2019 period. Due to the occurrence of drought conditions smaller streams in rural areas of Czechia have suffered from a low water quality, especially in the summer. For these reasons, the Mastník stream contributes to the abnormal eutrophication of the Mastník bay. Since the exchange of water between the bay and the rest of the Slapy reservoir has been limited, a large increase in the phytoplankton biomass has been observed in the Mastník bay. Consequently, the concentrations of chlorophyll in the Mastník bay increased over the last 15 years, with the chlorophyll- $\alpha$ concentration exceeding $500 \mu \mathrm{g} \mathrm{I}^{-1}$ during the summer months in several cases. Based on the concentrations of total nitrogen, total phosphorus, chlorophyll and water transparency measured by this study, the Mastník bay is evaluated as being hypertrophic. In contrast, no significant effect of the Mastník bay on the concentrations of the monitored parameters has been demonstrated in the remaining parts of the Slapy Reservoir.
\end{abstract}

\section{KEYWORDS}

Mastník bay; Slapy Reservoir (Vltava River); surface water quality; eutrophication; trophic state

Received: 16 January 2020

Accepted: 30 December 2020

Published online: 19 February 2021

Mrkva, L., Janský, B., Šobr, M. (2021): Eutrophication of the Mastník bay of the Slapy Reservoir, Czechia.

AUC Geographica 56(1), 65-78

https://doi.org/10.14712/23361980.2021.2

(C) 2021 The Authors. This is an open-access article distributed under the terms of the Creative Commons Attribution License (http://creativecommons.org/licenses/by/4.0). 


\section{Introduction}

Two important goals of water resources management are to restrict pollution sources and to prevent worsening of surface water quality. Eutrophication has become the primary problem facing most surface water bodies worldwide (Guo et al. 2018). Climate change also had a significant negative effect on water quality (Viney et al. 2007). According to research results, water management is an area that could be highly affected by climate change, especially in relation to water temperature and discharge (Novický et al. 2006).

Small watercourses in rural areas often show many unsecured water pollution sources. Restriction of water pollution sources is a major theme in the expert community. Surface water quality has improved over the last 25 years, primarily as a result of restriction of pollution point sources through the closing of many factories, reconstruction and modernization of technological methods in industry, and the building or modernization of sanitation and wastewater treatment plants (WWTPs) (Government of the Czech Republic 2018). Despite these efforts water quality of some small watercourses is still very poor. The problem of diffuse sources of water pollution such as rural settlements and agriculture remains unsolved (Taylor et al. 2016).

Primary production, especially that of phytoplankton, is used as a sensitive and accurate indicator for eutrophication assessment. Rosa and Michelle (2007) asserted the chlorophyll- $\alpha$ is the best practical measure of eutrophication problem. The chlorophyll- $\alpha$ level is related to a great number of hydrological, geochemical and ecological variables that impact phytoplankton growth (Park et al. 2015). In general, during the growing season eutrophication of lakes and reservoirs is strongly dependent on the release of nutrients, especially phosphorus, leading to increased

Tab 1. Limnological variables for the Mastník bay and the Slapy Reservoir.

\begin{tabular}{|c|c|c|}
\hline & Mastník bay & Slapy Reservoir \\
\hline Location & \multicolumn{2}{|l|}{ Central Bohemia } \\
\hline Origin & $\begin{array}{l}\text { part of the } \\
\text { Slapy Reservoir }\end{array}$ & $\begin{array}{l}\text { built in } \\
\text { 1949-1955 }\end{array}$ \\
\hline Geographic coordinates & $\begin{array}{l}49.7334436 \mathrm{~N}, \\
14.4132933 \mathrm{E}\end{array}$ & $\begin{array}{l}49.8238797 \mathrm{~N}, \\
14.4341139 \mathrm{E}\end{array}$ \\
\hline Length $[\mathrm{km}]$ & 4.7 & 44 \\
\hline Depth [m] & $0.5-40$ & max. 53, avg. 20.7 \\
\hline Width $[\mathrm{m}]$ & $4-230$ & $x$ \\
\hline Volume $\left[\mathrm{m}^{3}\right]$ & 6000000 & 269300000 \\
\hline Catchment area $\left[\mathrm{km}^{2}\right]$ & about 330 & 12900 \\
\hline Average inflow $\left[\mathrm{m}^{3} \cdot \mathrm{s}^{-1}\right]$ & 1.26 & 83.4 \\
\hline Average outflow $\left[\mathrm{m}^{3} \cdot \mathrm{s}^{-1}\right]$ & $x$ & 84.7 \\
\hline Average retention time [day] & 55 & 36 \\
\hline
\end{tabular}

phytoplankton production (Smith 2013). The consequences show that the most significant risk for river eutrophication is posed by point rather than diffuse phosphorus sources, even in rural areas with high phosphorus losses in agriculture (Jarvie et al. 2006). Classification of lakes based on various methods and indices have been made by various workers. The classical and most commonly used method, based on the productivity of the water body, is the biomass related trophic state index (TSI) developed by Carlson (1977). Based on the TSI and similar index, trophies of lakes and reservoirs around the world have been elucidated (Burns et al. 2005; El-Serehy et al. 2018; Guo et al. 2018; Hamilton and Parparov 2010; Prasad 2012; Worako 2015).

The Mastník bay at the Slapy Reservoir was selected as the object of this study. The objectives of this study were to describe the trophic state and water quality of Mastník bay and ascertain its effect on the Slapy Reservoir. Thus, nutrients and oxygen concentrations, water temperature and biomass in the Mastník bay was investigated over three growing seasons (2016-2018).

\section{Materials and methods}

\subsection{Description of the study area}

The Mastník catchment area is located in the centre of Czechia (Central Europe). The Mastník stream flows into the Slapy Reservoir at approximately river kilometre 103 of the Vltava River. Figure 1 shows the location of the catchment area, including the Slapy Reservoir. About $70 \%$ of the Mastník catchment area is part of the Agriculture Soil Fund, reflecting the predominantly agricultural character of the catchment (Mrkva 2018). Industrial production is marginal in the catchment. The Mastník bay is $4.7 \mathrm{~km}$ long and

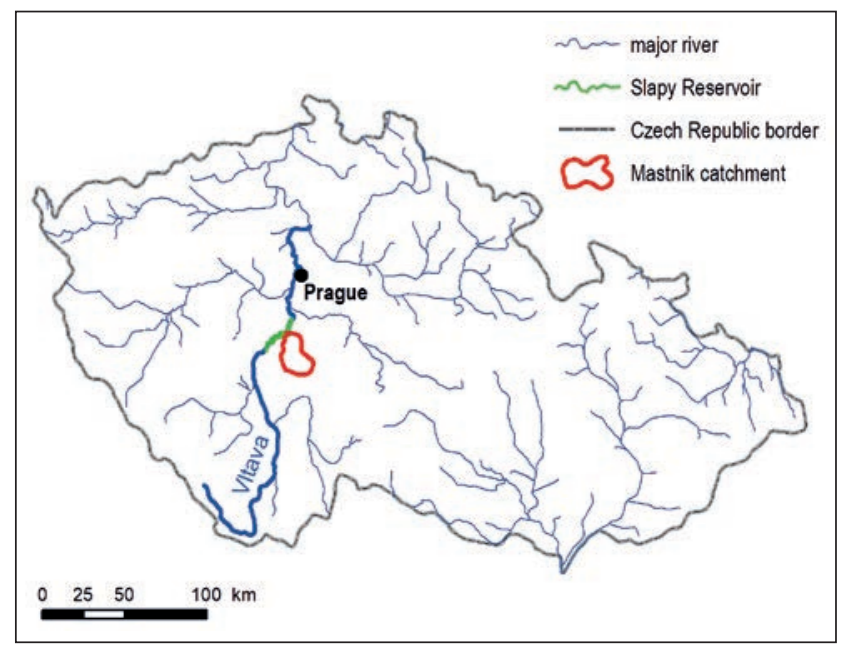

Fig. 1 Location of the Mastník catchment and the Slapy Reservoir in Czechia. 
about $230 \mathrm{~m}$ wide near its mouth to the main part of the reservoir. The volume of the bay is approximately 6 million $\mathrm{m}^{3}$, depending on the water level of the reservoir. The Slapy Reservoir was built between 1949 and 1955 and is the 6th largest reservoir in Czechia. Flow velocity in the Slapy Reservoir is low and the average retention time is 36 days (Procházková et al. 1996). Limnological variables and characteristics of bay and reservoir are presented in Table 1.

\subsection{Monitoring and dataset}

Sampling in the field took place from May to October (growing season) from 2016 to 2018. A total of 160 water samples were collected from six locations selected in the Mastník bay. Each sampling location is shown in Figure 2 (S2-S7). Mixed samples were taken at every sampling location. A mixed sample is defined as a sample from the upper water layer of the bay (max. depth $1.2 \mathrm{~m}$ ). At locations S3 and S4 vertical profiles from 5 - and 10-meters depths were collected using a depth sampler, while at location S5 only 5 meters depth (the bay bottom) was sampled. At these three locations the mixed sample is denoted Sx-1, the sample from a depth of $5 \mathrm{~m} \mathrm{Sx}-2$, and the sample from a depth of $10 \mathrm{~m} \mathrm{Sx}-3$. Further details are given in Table 2.

The number of sampling cruises varied from year to year, with monthly observation of an entire growing season only in 2016 and 2018. In the field, the collected water samples were subdivided into plastic bottles and transported to the laboratory for analysis immediately. Sample analyses were performed in the Laboratory for Water Protection at the Institute for Environmental Studies of the Faculty of Science of Charles University and in Water management laboratories of the Vltava River Basin Authority. The largest number of parameters were analysis in 2018: $\mathrm{N}-\mathrm{NO}_{2}{ }^{-}, \mathrm{N}-\mathrm{NO}_{3}{ }^{-}$, total nitrogen (TN), N- $\mathrm{NH}_{4}{ }^{+}, \mathrm{P}^{-} \mathrm{PO}_{4}{ }^{3-}$, total phosphorus (TP) and chlorophyll- $\alpha$ (Chl- $\alpha$ ). In contrast, in 2016 and 2017 the following parameters

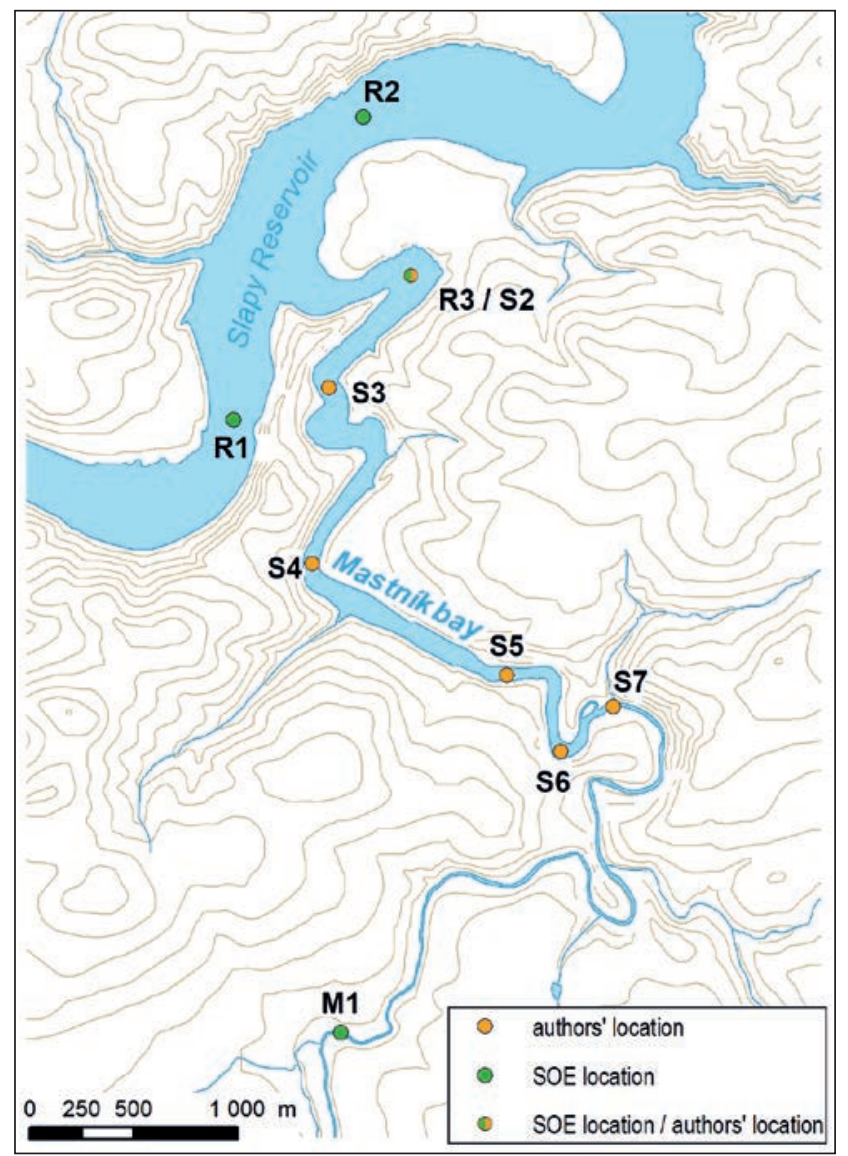

Fig. 2 Sampling locations.

were analysed: $\mathrm{N}^{-\mathrm{NO}_{3}}{ }^{-}, \mathrm{N}-\mathrm{NH}_{4}{ }^{+}, \mathrm{P}-\mathrm{PO}_{4}{ }^{3-}$ and $\mathrm{Chl}-\alpha$. In most cases a YSI multiparameter probe was used to record basic physical characteristics such as water temperature (WT), dissolved $\mathrm{O}_{2}$ (DO) and oxygen saturation (SO) throughout the water column. In several cases, the entire water column was not measured. Data with multiparameter probe were measured at $1 \mathrm{~m}$ intervals. Water transparency was measured using Secchi disc (SD), $20 \mathrm{~cm}$ in diameter and painted with contrasting black and white colours.

Tab. 2 Information about each sampling points.

\begin{tabular}{|c|c|c|c|c|}
\hline Location name & Distance to mouth [km] & Width [m] & Average depth [m] & Samples \\
\hline S2 & 0.55 & 249 & 25.0 & mixed sample from surface to $120 \mathrm{~cm}$ \\
\hline S3 & 1.30 & 102 & 20.0 & $\begin{array}{l}\text { mixed sample from surface to } 120 \mathrm{~cm} \text {, } \\
\text { sample from a depth of } 5 \mathrm{~m} \text {, } \\
\text { sample from a depth of } 10 \mathrm{~m}\end{array}$ \\
\hline S4 & 2.30 & 74 & 13.0 & $\begin{array}{l}\text { mixed sample from surface to } 120 \mathrm{~cm} \text {, } \\
\text { sample from a depth of } 5 \mathrm{~m} \text {, } \\
\text { sample from a depth of } 10 \mathrm{~m}\end{array}$ \\
\hline S5 & 3.30 & 54 & 5.0 & $\begin{array}{l}\text { mixed sample from surface to } 120 \mathrm{~cm} \text {, } \\
\text { sample from a depth of } 5 \mathrm{~m}\end{array}$ \\
\hline S6 & 4.00 & 54 & 1.5 & mixed sample from surface to $120 \mathrm{~cm}$ \\
\hline S7 & 4.30 & 30 & 0.7 & mixed sample from surface to $120 \mathrm{~cm}$ \\
\hline M1 & 8.10 & 3 & \multirow{2}{*}{\multicolumn{2}{|c|}{ Dataset from Vltava River Basin Authority (SOE) }} \\
\hline \multicolumn{3}{|l|}{$\mathrm{R} 1, \mathrm{R} 2, \mathrm{R} 3$} & & \\
\hline
\end{tabular}


The authors' dataset was extended with data provided by the Vltava River Basin Authority (SOE), which included vertically resolved sampling at three locations within the Slapy Reservoir, as well as on the last sampling location on the Mastník stream before it enters the Mastník bay (M1). One of the sites at the reservoir (R3) corresponds to the authors' location S2; the other sites (R1 and R2) are located up and downstream along the longitudinal axis of the reservoir (see Fig. 2). Data from SOE were available from 2005 to 2016 at monthly intervals from April to October. For reservoir locations, data from the entire water column and mixed samples (upper layer to max. depth of $2 \mathrm{~m}$ ) were available. Unfortunately, the SOE dataset did not form a continuous series, and the number of monitored parameters varied by year.

\subsection{Assessment of water quality}

Monitored water quality parameters in the Mastník bay were evaluated based on concentrations along longitudinal and vertical profiles. Emphasis was placed on ascertaining change in concentrations of nutrients and chlorophyll- $\alpha$ over time, enabling comparisons between the monitored years, especially between 2016 and 2018.

For the overall assessment of water quality, it is recommended to classify the results for two years. From the measured concentrations, the mean, median and characteristic value of C(90), which is defined as the value with a no-overrun probability of $90 \%$ were calculated. This value is based on the Czech Standard Classification of Surface Water Quality (ČSN 75 7221). In the case of evaluation of location M1, R1, R2 and R3, the two years 2015 and 2016 were used. There were 14 determinations available at location R1, $\mathrm{R} 2$ and R3. That mean the characteristic value was the second-highest when sorting concentrations in ascending order. In the case of dissolved oxygen, the series was formed in descending order. At a frequency of 24 or more values over the evaluated period (as at location M1), the value of C (90) was calculated according to the equation 1 :

$$
C(90)=\left(d_{90} \cdot C_{k-1}\right)+\left(1-d_{90}\right) C_{k}
$$

where

$C_{k}=k$-th value in descending order

(for DO ascending),

$C_{k-1}=(k-1)$-th value in descending order

(for DO ascending),

and

$d_{90}=$ variable value, calculated according to the equation 2 :

$d_{90}=(k-10) / 100 \cdot(n+0.4)-0.3$

where

$n=$ number of values (24 or more) and

$k=$ variable value, which is calculated according to the equation 3 :

$$
k=10 / 100 \cdot(n+0.4)-0.3
$$

and rounded up to an integer.

The most commonly used method for classification and characterization of surface water trophic state is the trophic index. In this study, two indexes were used: Carlson's Trophic State Index (CTSI) and Trophic Level Index (TLI). These methods use Secchi disc transparency and chlorophyll, TP and TN concentrations. CTSI can be used for regional classification of all surface waters, including streams and rivers in temperate climate. TSI was calculated according to the following equation 4 (Carlson 1977):

$$
C T S I=[T S(T P)+T S(C h l)+T S(S D)] / 3
$$

where

$$
\begin{aligned}
& T S(T P)=14.42 \operatorname{Ln}(T P)+4.15 \\
& T S(C h l)=9.81 \operatorname{Ln}(C h l-\alpha)+30.6, \\
& T S(S D)=60-14.41 \operatorname{Ln}(S D) .
\end{aligned}
$$

TLI, which also includes TN term, was calculated using the following equation 5 (Burns et al . 2005):

$$
\begin{aligned}
& T L I=[T L(T P)+T L(T N)+T L(C h l)+T L(S D)] / 4 \\
& \text { where } \\
& T L(T P)=2.92 \log (T P)+0.218 \\
& T L(T N)=3.01 \log (T N)-3.61 \\
& T L(C h l)=2.54 \log (C h l-\alpha)+2.22 \\
& T L(S D)=5.1+2.6 \log (1 / S D-1 / 40)
\end{aligned}
$$

Based on the calculated values, the monitored profiles were classified into trophic classes. Division into classes is given in Table 3 .

The dependence of chlorophyll- $\alpha$ on TP concentration was calculated using the correlation coefficient (CC). Due to the low number of observations, the CC results could not be considered as statistically significant at a significance level of alpha $=0.05$. Only 6 values are available it thy study. If the CC for 6 samples is higher than 0.7067 , the dependence may be considered significant (Heo et al. 2008).

Tab. 3 Classes of trophic index.

\begin{tabular}{|l|c|c|}
\hline TI classification & CTSI & TLI \\
\hline Oligotrophic & 21 to 41 & 2 to 3 \\
\hline Mesotrophic & 41 to 50 & 3 to 4 \\
\hline Eutrophic & 51 to 60 & 4 to 5 \\
\hline Supertrophic & & 5 to 6 \\
\hline Hypertrophic & over 61 & 6 to 7 \\
\hline
\end{tabular}


Tab. 4 Water quality of state sampling station M1 (2015-2016).

\begin{tabular}{|c|c|c|c|}
\hline Station & & M1 & \\
\hline Component/Index & Mean & Median & C (90) \\
\hline Water temperature $\left[{ }^{\circ} \mathrm{C}\right]$ & 11.21 & 11.50 & \\
\hline Dissolved oxygen [mg I-1] & 11.20 & 11.40 & 8.17 \\
\hline Saturation $\mathrm{O}_{2}[\%]$ & 102.17 & 99.00 & \\
\hline $\mathrm{TN}\left[\mathrm{mg} \mathrm{l}^{-1}\right]$ & 4.28 & 3.70 & 6.86 \\
\hline $\mathrm{N}-\mathrm{NH}_{4}{ }^{+}\left[\mathrm{mg} \mathrm{I}^{-1}\right]$ & 0.10 & 0.10 & 0.20 \\
\hline $\mathrm{N}-\mathrm{NO}_{3}^{-}\left[\mathrm{mg} \mathrm{l}^{-1}\right]$ & 3.50 & 3.10 & 5.74 \\
\hline $\mathrm{N}-\mathrm{NO}^{2-}\left[\mathrm{mg} \mathrm{l}^{-1}\right]$ & 0.04 & 0.00 & 0.07 \\
\hline $\mathrm{TP}\left[\mathrm{mg} \mathrm{l}^{-1}\right]$ & 0.24 & 0.20 & 0.45 \\
\hline Chlorophyll- $\alpha$ [ug I-1] & 28.98 & 20.50 & 55.00 \\
\hline
\end{tabular}

By comparison of datasets from the R1 and R2 locations, the possible effect of the Mastník stream on water quality in the Slapy Reservoir was evaluated. In the case of longer time-series datasets from the reservoir (i.e. R1, R2 and R3), the Mann-Kenndall statistical test (MKT) was used to evaluate the trend. Seasonal MKTs were performed on year time-series of concentrations for the R1, R2, R3 profile and to a monthly time-series of concentrations for the M1 for the period 1995-2016. The significance of the trend was tested at a level of alpha $=0.1$.

\section{Results}

\subsection{Surface water quality in the Mastník catchment area}

The last sampling location on the Mastník stream before it enters Mastník bay is the Radíc station (M1). This station represents the catchment load and yields concentrations of pollutants coming from most of the catchment area (approximately $81 \%$ of the catchment area). Because of high concentrations of chlorophyll- $\alpha$ and total phosphorus, the water at this sampling location is identified as highly polluted (Mrkva 2018). The concentrations of all monitored parameters between 1995 and 2016 decreased. For selected parameters, this trend was confirmed by the MKT test, which showed a significant downward trend in the case of $\mathrm{TP}, \mathrm{N}-\mathrm{NH}_{4}{ }^{+}, \mathrm{N}-\mathrm{NO}_{3}{ }^{-}$and $\mathrm{N}-\mathrm{NO}^{2-}$. Only in the case of chlorophyll- $\alpha$ a slight increase was observed, with the average concentration being $20.12 \mu \mathrm{g} \mathrm{I}^{-1}$ in 2002 and increasing to $28.9 \mu \mathrm{g} \mathrm{I}^{-1}$ in 2016 . However, the results could not be considered significant. Also, in the case of surface water temperature, an increase in the average value was observed, from $9.9^{\circ} \mathrm{C}$ in 1997 to $11.2^{\circ} \mathrm{C}$ in 2016. WT varied between $10.6^{\circ} \mathrm{C}$ and $20.2{ }^{\circ} \mathrm{C}$ in the growing season of the monitored period. The average water temperature during these growing seasons was $15.9^{\circ} \mathrm{C}$. During investigated growing seasons the average contribution of TP to the bay was $278 \mathrm{~kg}$ per month. In contrast, the long-term average TP load, which is based on concentration from year-round measurements, was $845 \mathrm{~kg}$ per month. Contribution of TN was $1450 \mathrm{~kg}$ per month during investigated growing seasons. These values were calculated based on the concentrations reached at the M1 station.

\subsection{Seasonal variations of different water quality parameters in Mastník bay}

\subsubsection{Water temperature and oxygen regime}

WT varied between 5.1 and $26.1{ }^{\circ} \mathrm{C}$ during the growing season in the monitored period. The coldest year was 2016, in which the surface layer water temperature varied between $10^{\circ} \mathrm{C}$ in May and $21^{\circ} \mathrm{C}$ in August. In 2017 and 2018 water temperatures exceeded $20^{\circ} \mathrm{C}$ from June to September. The August maxima exceeded $23^{\circ} \mathrm{C}$ in 2017 and $25^{\circ} \mathrm{C}$ in 2018 , respectively. The minimum values for water temperature were recorded in October.

Vertical profiles at $\mathrm{S} 1-\mathrm{S} 5$ show significant temperature stratification. In the summer months of 2018

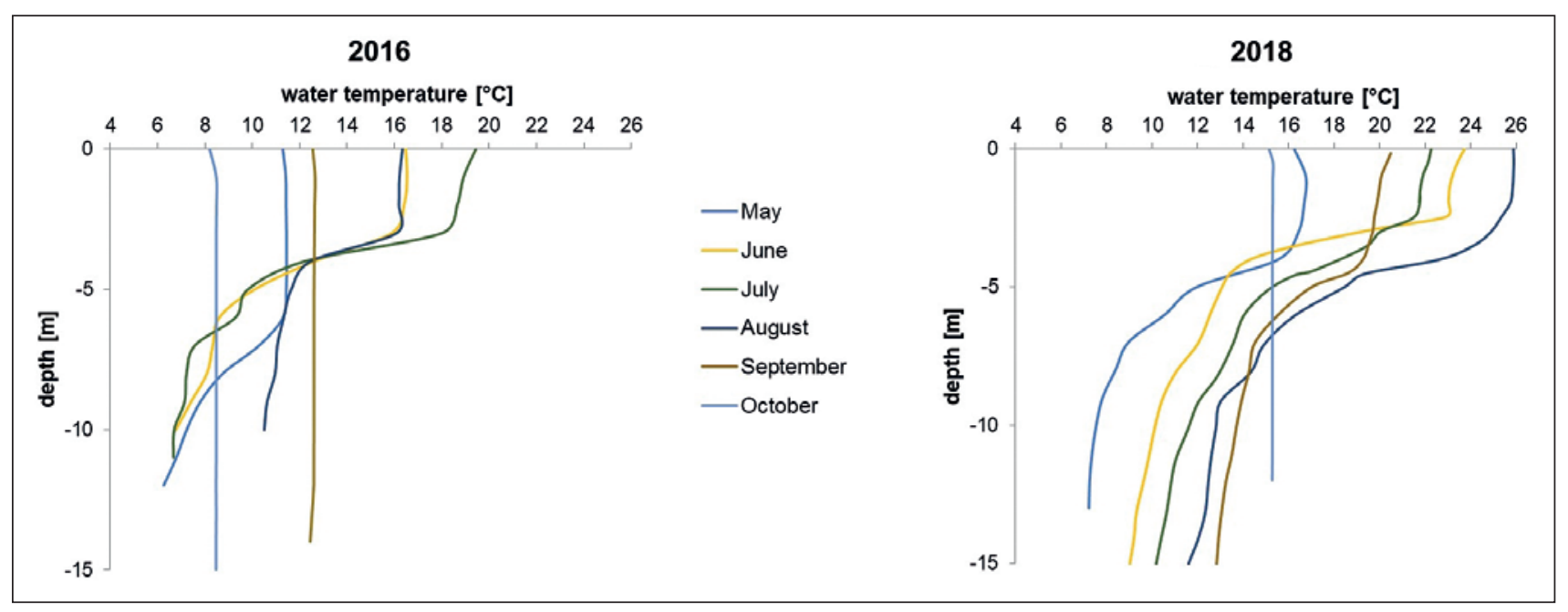

Fig. 3 Thermal stratification - vertical profiles at S3 $(2016,2018)$. 


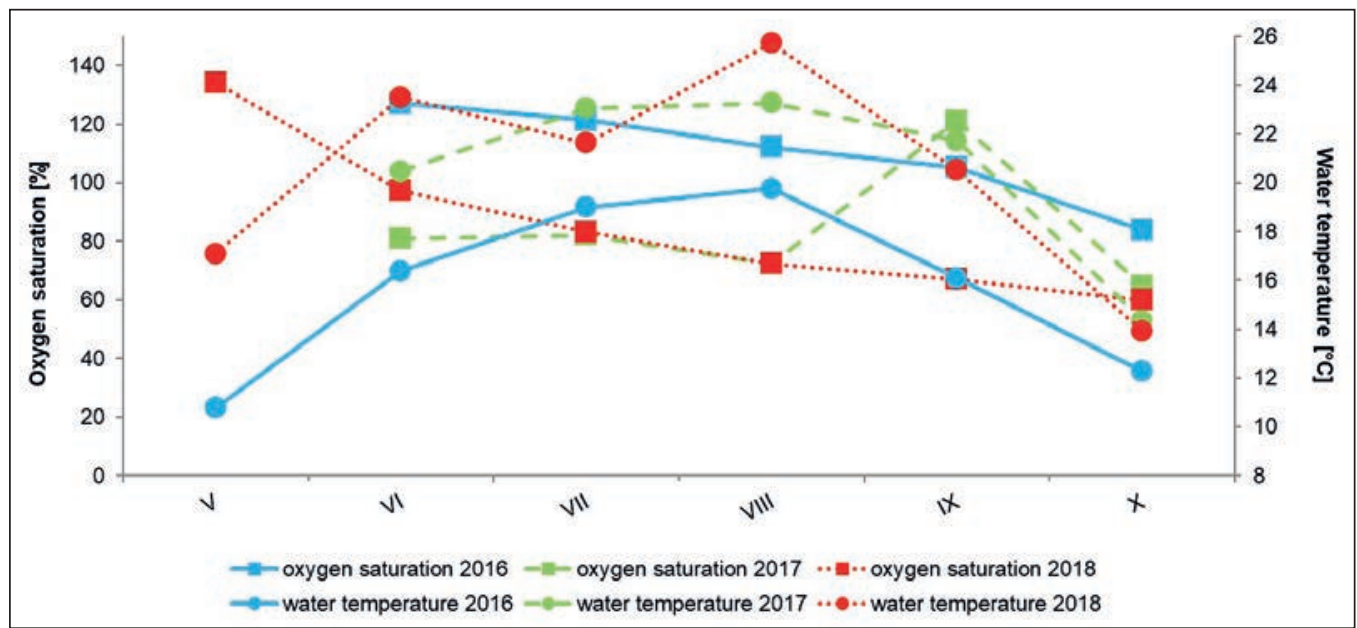

Fig. 4 Water temperature and oxygen saturation (comparison of growing periods, 2016, 2017 and 2018).

water temperature in the epilimnion was approximately $26{ }^{\circ} \mathrm{C}$, compared to a water temperature of approximately $14{ }^{\circ} \mathrm{C}$ in lower layers of the bay. Comparison of stratification development during the growing season is shown at S3 for both years in Figure 3. As can be seen from the figure, the thermocline started during the summer at a depth between 4 and 5 meters. In September and October of 2016 and October of 2018, the temperature profile showed uniformity throughout the water column at $\sim 12{ }^{\circ} \mathrm{C}$ and $\sim 15{ }^{\circ} \mathrm{C}$. However, it is necessary to include the effect of reservoir water level manipulation in interpreting these results, since in October the water level in the reservoir decreases every year. While the sampling campaign started in April each year, the end of the spring circulation was not observed. In terms of longitudinal temperature development in bay, the difference between station S7 and S2 ranges from 1 to $2{ }^{\circ} \mathrm{C}$ in mixed samples. Towards to station S2 the temperature increases.
The solubility of oxygen in water is affected by temperature, with the solubility of oxygen decreasing as water temperature increases. Figure 4 compares the average monthly OS and WT values of all monitored stations in the growing season for the years 2016, 2017 and 2018. From these average values, it is evident that the highest saturation values were reached in 2016, when the lowest water temperatures occurred. The years 2017 and 2018 showed very similar patterns of relationship between these two parameters.

In the Mastník bay, oxygen concentration varied greatly from year to year. In 2016, there was adequate oxygen in the upper layer of bay water, compared to other monitored years. DO concentrations of 2016 were usually higher than $7.5 \mathrm{mg} \mathrm{I}^{-1}$. In 2016, oxygen deficits occurred at greater depths, as shown in stratification diagram (Fig. 5). For example, the oxygen concentration S33 samples, taken from depth of 10 meters concentration decrease during the summer

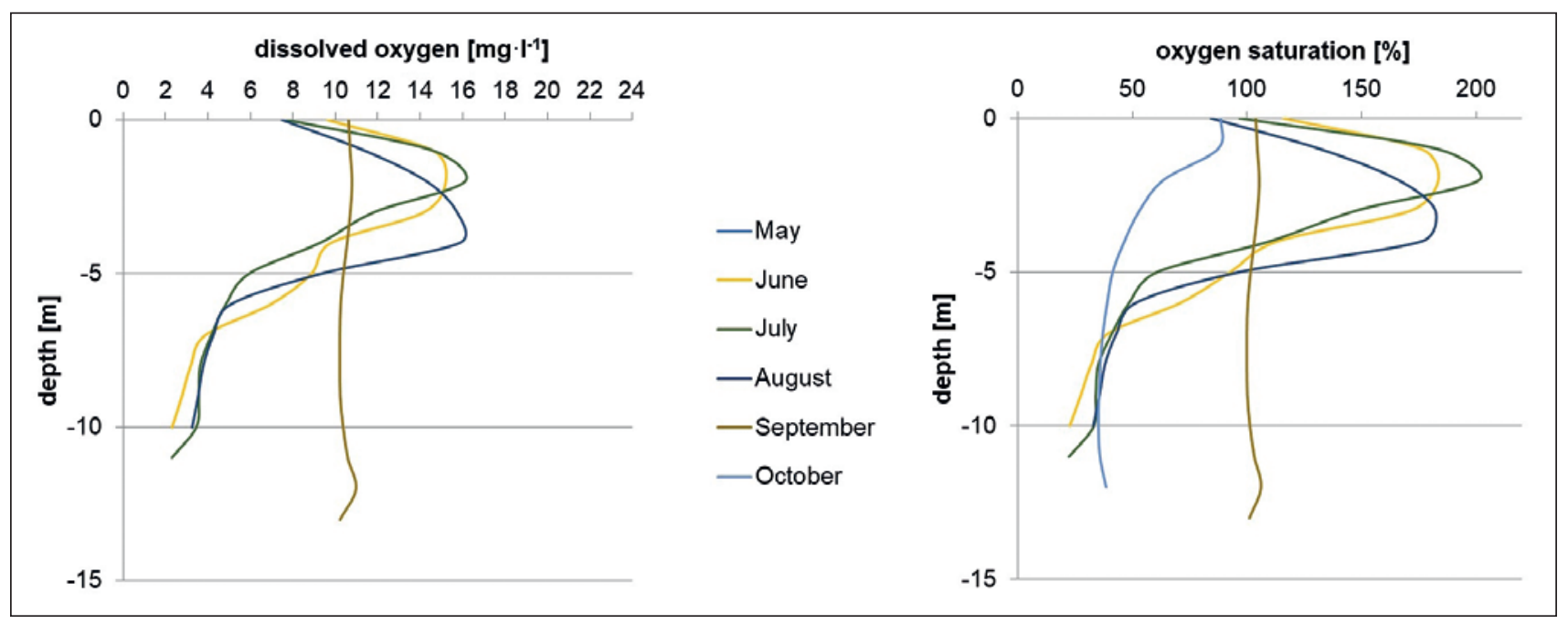

Fig. 5 Stratification of dissolved oxygen and oxygen saturation: vertical profiles at S4 in 2016 . 
Tab. 5 Dissolved oxygen concentration and oxygen saturation in Mastník bay.

\begin{tabular}{|c|c|c|c|c|c|c|c|c|c|c|c|c|}
\hline \multirow{3}{*}{$\begin{array}{l}\text { Month } \\
\text { Station }\end{array}$} & \multicolumn{12}{|c|}{2016} \\
\hline & \multicolumn{2}{|l|}{ V } & \multicolumn{2}{|c|}{ VI } & \multicolumn{2}{|c|}{ VII } & \multicolumn{2}{|c|}{ VIII } & \multicolumn{2}{|c|}{ IX } & \multicolumn{2}{|l|}{$x$} \\
\hline & $\mathrm{DO}\left[\mathrm{mg} \mathrm{l}^{-1}\right]$ & OS [\%] & $\mathrm{DO}\left[\mathrm{mg} \mathrm{I}^{-1}\right]$ & OS [\%] & $\mathrm{DO}\left[\mathrm{mg} \mathrm{I}^{-1}\right]$ & OS [\%] & $\mathrm{DO}\left[\mathrm{mg} \mathrm{I}^{-1}\right]$ & OS [\%] & $\mathrm{DO}\left[\mathrm{mg} \mathrm{l}^{-1}\right]$ & OS [\%] & $\mathrm{DO}\left[\mathrm{mg} \mathrm{l}^{-1}\right]$ & OS [\%] \\
\hline S2 & $x$ & $x$ & 9.29 & 109.80 & 9.31 & 115.30 & 7.65 & 87.30 & 9.76 & 94.60 & 7.00 & 63.90 \\
\hline S3-1 & $x$ & $x$ & 9.28 & 109.30 & 9.36 & 116.50 & 7.20 & 78.80 & 10.26 & 99.80 & 10.24 & 92.80 \\
\hline S3-2 & $x$ & $x$ & 8.76 & 89.30 & 6.82 & 68.90 & 9.00 & 91.30 & 7.76 & 75.70 & 4.36 & 39.80 \\
\hline S3-3 & $x$ & $x$ & 5.23 & 53.80 & 6.49 & 60.30 & 3.40 & 33.60 & 7.52 & 73.30 & 3.87 & 35.40 \\
\hline S4-1 & $x$ & $x$ & 9.62 & 115.80 & 7.70 & 96.70 & 7.49 & 84.10 & 10.63 & 103.90 & 9.80 & 88.50 \\
\hline S4-2 & $x$ & $x$ & 8.87 & 92.70 & 5.95 & 60.70 & 9.34 & 96.70 & 10.38 & 101.50 & 4.55 & 41.40 \\
\hline S4-3 & $x$ & $x$ & 2.31 & 22.70 & 3.45 & 33.10 & 3.26 & 32.80 & 10.37 & 101.20 & 3.88 & 35.20 \\
\hline S5-1 & $x$ & $x$ & 12.32 & 150.60 & 9.21 & 116.40 & 13.79 & 161.40 & 10.76 & 105.40 & 10.11 & 90.00 \\
\hline S5-2 & $x$ & $x$ & 7.57 & 90.60 & 2.36 & 25.30 & 9.49 & 102.80 & 12.26 & 116.10 & $x$ & $x$ \\
\hline S6 & $x$ & $x$ & 9.71 & 118.80 & 13.68 & 175.30 & 15.10 & 173.60 & 11.80 & 112.00 & $x$ & $x$ \\
\hline S7 & $x$ & $x$ & 13.12 & 160.00 & 10.29 & 130.10 & 7.69 & 86.80 & 13.59 & 126.20 & $x$ & $x$ \\
\hline
\end{tabular}

\begin{tabular}{|c|c|c|c|c|c|c|c|c|c|c|c|c|}
\hline \multirow{3}{*}{$\begin{array}{l}\text { Month } \\
\text { Station }\end{array}$} & \multicolumn{12}{|c|}{2017} \\
\hline & \multicolumn{2}{|c|}{ v } & \multicolumn{2}{|c|}{ VI } & \multicolumn{2}{|c|}{ VII } & \multicolumn{2}{|c|}{ VIII } & \multicolumn{2}{|c|}{ IX } & \multicolumn{2}{|c|}{$\mathrm{x}$} \\
\hline & $\mathrm{DO}\left[\mathrm{mg} \mathrm{l}^{-1}\right]$ & OS [\%] & $\mathrm{DO}\left[\mathrm{mg} \mathrm{l}^{-1}\right]$ & OS [\%] & $\mathrm{DO}\left[\mathrm{mg} \mathrm{l}^{-1}\right]$ & OS [\%] & $\mathrm{DO}\left[\mathrm{mg} \mathrm{I}^{-1}\right]$ & OS [\%] & $\mathrm{DO}\left[\mathrm{mg} \mathrm{l}^{-1}\right]$ & OS [\%] & $\mathrm{DO}\left[\mathrm{mg} \mathrm{l}^{-1}\right]$ & OS [\%] \\
\hline $\mathrm{S} 2$ & $x$ & $x$ & 6.75 & 75.30 & 4.70 & 54.90 & 5.68 & 66.90 & 6.49 & 74.23 & 6.09 & 60.80 \\
\hline S3-1 & $x$ & $x$ & 7.21 & 80.60 & 5.49 & 64.60 & 4.21 & 49.70 & 6.17 & 70.57 & 6.95 & 69.30 \\
\hline S3-2 & $x$ & $x$ & 7.98 & 76.00 & 5.89 & 59.50 & 3.64 & 39.20 & 7.26 & 75.10 & 6.14 & 61.30 \\
\hline S3-3 & $x$ & $x$ & 8.84 & 79.40 & 6.90 & 64.80 & 3.54 & 35.60 & 7.68 & 76.80 & 6.19 & 61.70 \\
\hline S4-1 & $\mathrm{x}$ & $\mathrm{x}$ & 8.13 & 91.00 & 5.87 & 68.70 & 5.13 & 60.50 & 5.13 & 58.68 & 6.13 & 61.20 \\
\hline S4-2 & $\mathrm{x}$ & $\mathrm{x}$ & 8.87 & 83.50 & 6.39 & 65.10 & 3.79 & 42.30 & 7.91 & 82.40 & 6.17 & 61.60 \\
\hline S4-3 & $\mathrm{x}$ & $x$ & 9.60 & 87.00 & 7.94 & 74.50 & 3.51 & 35.00 & 8.63 & 86.30 & 6.28 & 62.50 \\
\hline S5-1 & $x$ & $x$ & 9.16 & 102.10 & 7.53 & 88.20 & 6.89 & 80.60 & 10.17 & 114.27 & 6.79 & 67.60 \\
\hline S5-2 & $x$ & $x$ & 11.93 & 115.80 & 7.65 & 84.10 & 7.13 & 81.90 & 5.54 & 61.56 & 7.22 & 69.00 \\
\hline S6 & $x$ & $x$ & 7.93 & 88.00 & 10.62 & 122.80 & 11.23 & 80.30 & 8.17 & 93.45 & 8.30 & 78.30 \\
\hline S7 & $x$ & $x$ & 5.22 & 57.00 & 10.43 & 120.20 & 12.14 & 140.10 & 13.69 & 152.11 & 6.84 & 62.90 \\
\hline
\end{tabular}

\begin{tabular}{|c|c|c|c|c|c|c|c|c|c|c|c|c|}
\hline \multirow{3}{*}{$\begin{array}{l}\text { Month } \\
\text { Station }\end{array}$} & \multicolumn{12}{|c|}{2018} \\
\hline & \multicolumn{2}{|c|}{ v } & \multicolumn{2}{|l|}{ VI } & \multicolumn{2}{|c|}{ VII } & \multicolumn{2}{|c|}{ VIII } & \multicolumn{2}{|c|}{ IX } & \multicolumn{2}{|l|}{$x$} \\
\hline & $\mathrm{DO}\left[\mathrm{mg} \mathrm{l}^{-1}\right]$ & OS [\%] & $\mathrm{DO}\left[\mathrm{mg} \mathrm{l}^{-1}\right]$ & OS [\%] & $\mathrm{DO}\left[\mathrm{mg} \mathrm{l}^{-1}\right]$ & OS [\%] & $\mathrm{DO}\left[\mathrm{mg} \mathrm{I}^{-1}\right]$ & OS [\%] & $\mathrm{DO}\left[\mathrm{mg} \mathrm{l}^{-1}\right]$ & OS [\%] & $\mathrm{DO}\left[\mathrm{mg} \mathrm{l}^{-1}\right]$ & OS [\%] \\
\hline S2 & 12.59 & 129.60 & 6.72 & 79.10 & 3.57 & 40.90 & 5.33 & 65.80 & 4.81 & 53.80 & 5.60 & 52.40 \\
\hline S3-1 & 12.90 & 132.90 & 7.78 & 92.10 & 4.39 & 50.50 & 6.35 & 78.10 & 5.43 & 60.30 & 3.80 & 38.00 \\
\hline S3-2 & 15.72 & 145.90 & 6.93 & 65.90 & 5.82 & 57.80 & 6.40 & 68.30 & 6.49 & 67.20 & 3.85 & 38.40 \\
\hline S3-3 & 17.35 & 144.90 & 7.01 & 62.30 & 6.50 & 59.80 & 7.42 & 70.10 & 6.96 & 66.80 & 3.86 & 38.60 \\
\hline S4-1 & 12.36 & 134.20 & 9.32 & 110.40 & 7.24 & 82.60 & 4.81 & 59.40 & 6.25 & 69.80 & 4.49 & 44.90 \\
\hline S4-2 & 13.91 & 134.40 & 8.25 & 79.30 & 7.76 & 77.60 & 8.42 & 89.50 & 6.75 & 71.80 & 4.65 & 46.40 \\
\hline S4-3 & 17.56 & 148.70 & 8.75 & 77.70 & 8.20 & 75.20 & 9.87 & 93.20 & 7.93 & 77.00 & 4.57 & 45.50 \\
\hline S5-1 & 15.45 & 158.20 & 8.24 & 98.20 & 8.63 & 97.90 & 10.98 & 134.90 & 6.86 & 76.20 & 4.80 & 46.70 \\
\hline S5-2 & 12.95 & 125.20 & 6.15 & 61.10 & 8.45 & 94.10 & 13.69 & 149.20 & 7.43 & 80.60 & 5.44 & 50.30 \\
\hline S6 & 10.95 & 116.00 & 8.01 & 94.40 & 8.64 & 97.70 & 3.44 & 42.00 & 7.80 & 86.20 & 12.40 & 117.20 \\
\hline S7 & $x$ & $x$ & 10.17 & 117.40 & 11.60 & 129.60 & $x$ & $x$ & $x$ & $x$ & $x$ & $x$ \\
\hline
\end{tabular}

to value below $4 \mathrm{mg} \mathrm{I}^{-1}$. All concentrations lower than $4 \mathrm{mg} \mathrm{I}^{-1}$ are highlighted in the Table 5. The table also shows higher oxygen concentrations in the part of the bay furthest away from the reservoir, which is the result of the inflow of fresh water from the basin and higher biological activity. In deeper zones, OS may remain below $100 \%$ due to the respiration of aquatic organisms and microbial decomposition. Additionally, these deeper levels of water often do not reach 100\% oxygen saturation because they are not affected by waves and photosynthetic at activity near surface. The observed oxygen concentration in August of 2017 fell below $40 \%$ oxygen saturation.

An example of oxygen stratification is represented in Figure 5. These diagrams show stratification in 2016 during growing season at sampling location S4. 


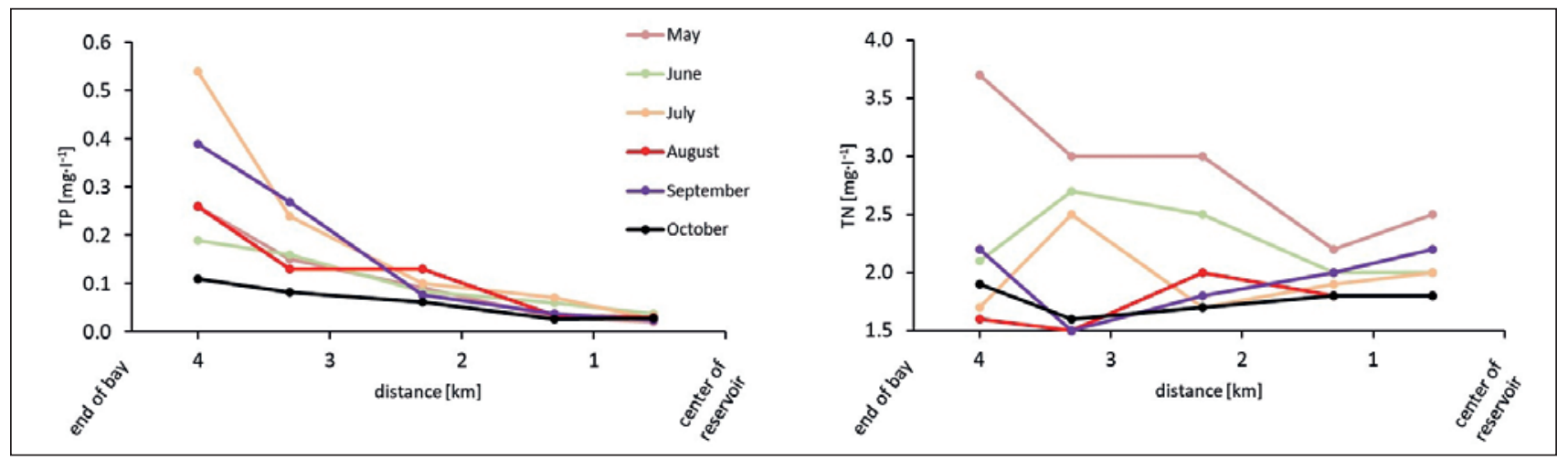

Fig. 6 Longitudinal profiles of TP and TN concentrations along Mastník bay in 2018 (mixed samples).

The curve trend shows clustering of photosynthesizing algae at depth of 3-5 m, resulting in an oxygen saturation higher than $100 \%$. A low oxygen zone (DO concentration below $4 \mathrm{mg} \mathrm{I}^{-1}$ ) in the lower part of the sampling profile (under $7 \mathrm{~m}$ ) is also apparent. This can partly be explained by sinking of organic material produced in the epilimnion to the thermocline, where oxidation reduces DO and oxygen saturation is about $50 \%$. This low oxygen condition occurred in 2016 in S3, S4 and S5 profiles. However, much higher amounts of oxygen in the epilimnion were observed during whole growing season 2016, which suggests high biogenic production by phytoplankton. In 2017, the low oxygen zone at the bottom was observed only in August, and in 2018 there were no observed low oxygen conditions at the bottom at all, with the exception of October, which was affected by the reduction of the water level by more than $1 \mathrm{~m}$.

\subsubsection{Nutrients concentration}

Nutrients are primarily compounds of nitrogen, phosphorus and silicon. In this study, the effect of silicon was not considered. An average TP concentration of $0.34 \mathrm{mg} \mathrm{I}^{-1}$ and TN concentration of $3.88 \mathrm{mg} \mathrm{I}^{-1}$ at the M1 station were measured. In the case of TP, this value is similar to the concentrations in the upper part of the bay, i.e. location S6 and S5. The concentrations ranged between 0.02 and $0.54 \mathrm{mg} \mathrm{I}^{-1}$. The maximum concentrations were found in July 2018. In the case of $\mathrm{TN}$, the maximum concentrations were in May and June, when the concentrations exceeded $4 \mathrm{mg} \mathrm{I}^{-1}$. TN concentrations ranged between 1.6 and $4.5 \mathrm{mg} \mathrm{I}^{-1}$. Higher TN values were found at greater depths. In the case of ammonia $\mathrm{N}$, highest concentrations were found in September, when the concentrations exceeded $0.6 \mathrm{mg} \mathrm{I}^{-1}$ along the entire longitudinal profile of the bay. In the case of TP concentrations gradually decreased in direction to the reservoir. Concentration changes from monthly observations along the longitudinal profile during 2018 are shown in Figure 6 , which shows that the highest entering concentrations were observed in July. Except for May and June, an increasing trend in the longitudinal profile can be seen in the case of TN. Concentrations of TN ranged from 1.5 to $2.5 \mathrm{mg} \mathrm{I}^{-1}$.

Because high amounts of phosphorus increase growth of algal biomass (eutrophication process), the dependence of chlorophyll concentrations on TP was calculated using the correlation coefficient. Results calculated for each station in 2018 are given in Table 6; results from mixed samples are highlighted. Due to the low number of observations, the correlation coefficient (CC) results could not be considered as statistically significant. The required value is only significant for chlorophyll concentration at station S4, because CC is higher than 0.7067 (Heo et al. 2008). All CC values for mixed samples showed positive correlation but were insignificant.

\subsubsection{Chlorophyll- $\alpha$ concentration and trophic indexes}

In the summer months, high levels of phytoplankton activity are clearly visible in the Mastník bay. Measurements of chlorophyll- $\alpha$ concentrations were used to estimate the total phytoplankton biomass. This method is simpler and faster than phytoplankton sampling and counting. However, as chlorophyll

Tab. 6 Significance of TP concentration and Chl- $\alpha$ concentration for 2018.

\begin{tabular}{|l|c|c|}
\hline Station & CC & Significance \\
\hline S2 & 0.28 & $x$ \\
\hline S3-1 & 0.56 & $x$ \\
\hline S3-2 & -0.10 & $x$ \\
\hline S3-3 & 0.11 & $x$ \\
\hline S4-1 & 0.87 & yes \\
\hline S4-2 & 0.56 & $x$ \\
\hline S4-3 & -0.23 & $x$ \\
\hline S5-1 & 0.70 & $x$ \\
\hline S5-2 & -0.33 & $x$ \\
\hline S6 & 0.49 & $x$ \\
\hline
\end{tabular}


Tab. 7 Trophic index for the Mastník bay in 2018.

\begin{tabular}{|c|c|c|c|c|c|c|c|c|}
\hline \multirow{2}{*}{ Station } & \multicolumn{4}{|c|}{ Components average value } & \multicolumn{4}{|c|}{ Trophic index } \\
\hline & SD [m] & TN [mg l-1] & $\mathrm{TP}\left[\mathrm{mg} \mathrm{l}^{-1}\right]$ & $\mathrm{Chl}-\alpha\left[\mu \mathrm{g} \mathrm{I}^{-1}\right]$ & \multicolumn{2}{|c|}{ CTSI } & \multicolumn{2}{|c|}{ TLI } \\
\hline S2 & 2.08 & 2.05 & 0.03 & 27.50 & 53.60 & eutrophic & 5.20 & supertrophic \\
\hline S3 & 1.50 & 1.95 & 0.04 & 41.33 & 58.15 & eutrophic & 5.51 & supertrophic \\
\hline S4 & 0.98 & 2.12 & 0.09 & 84.00 & 66.11 & hypertrophic & 6.09 & hypertrophic \\
\hline S5 & 0.81 & 2.13 & 0.17 & 152.83 & 71.31 & hypertrophic & 6.45 & hypertrophic \\
\hline S6 & 0.37 & 2.20 & 0.29 & 211.60 & 79.13 & hypertrophic & 6.96 & hypertrophic \\
\hline \multicolumn{5}{|c|}{ Overall total trophic index of Mastnik bay } & 65.66 & hypertrophic & 6.04 & hypertrophic \\
\hline
\end{tabular}

concentration assumes all phytoplankton to have the same levels of chlorophyll- $\alpha$, it provides only a rough estimate of biomass, and cannot be used to identify specific species. Chlorophyll concentration changes during the growing seasons of 2016 and 2018 along the Mastnik Bay can be displayed by sorting measured values of chlorophyll concentration into 5 categories. Figure 7 shows a schematic of chlorophyll concentrations divided into 5 classes based on values from mixed samples at different location. The schemes show that the upper part of the bay had much higher concentrations than elsewhere in the bay. Chlorophyll concentrations in the upper part of the bay exceeded $100 \mu \mathrm{g} \mathrm{I}^{-1}$ (represented in red), and at some location were above $500 \mu \mathrm{g} \mathrm{I}^{-1}$, as seen during July and August 2016. In 2018, lower values were observed at the same station. A maximum Chl- $\alpha$ concentration of $280 \mu \mathrm{g} \mathrm{I} \mathrm{I}^{-1}$ was reached in August at S6. During the growing seasons in 2016 and 2018 the pattern of areal distribution (Fig. 7) was similar, showing

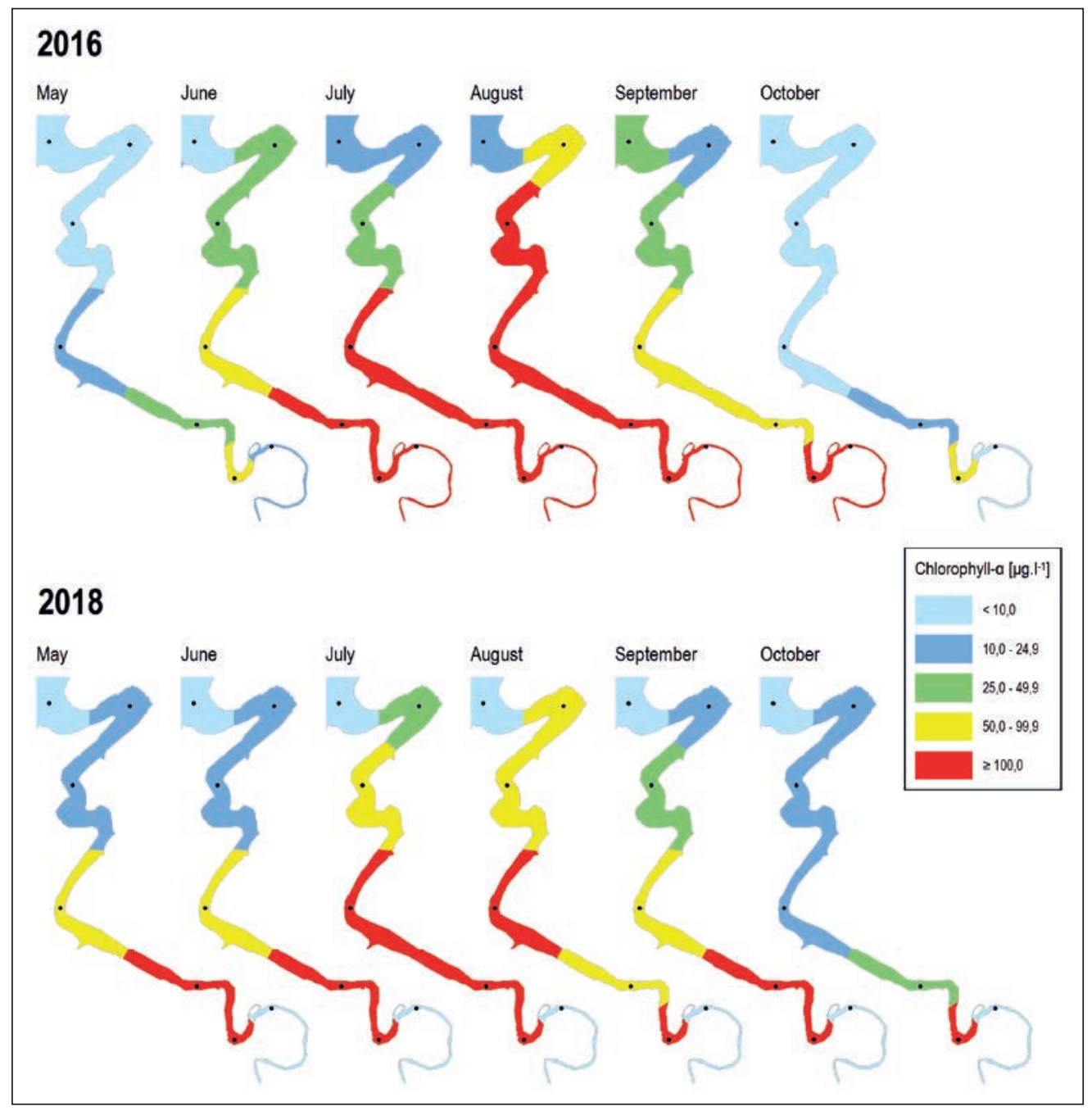

Fig. 7 Classification according to chlorophyll concentration along the longitudinal profile of the bay during the growing season (comparison 2016-2018). 


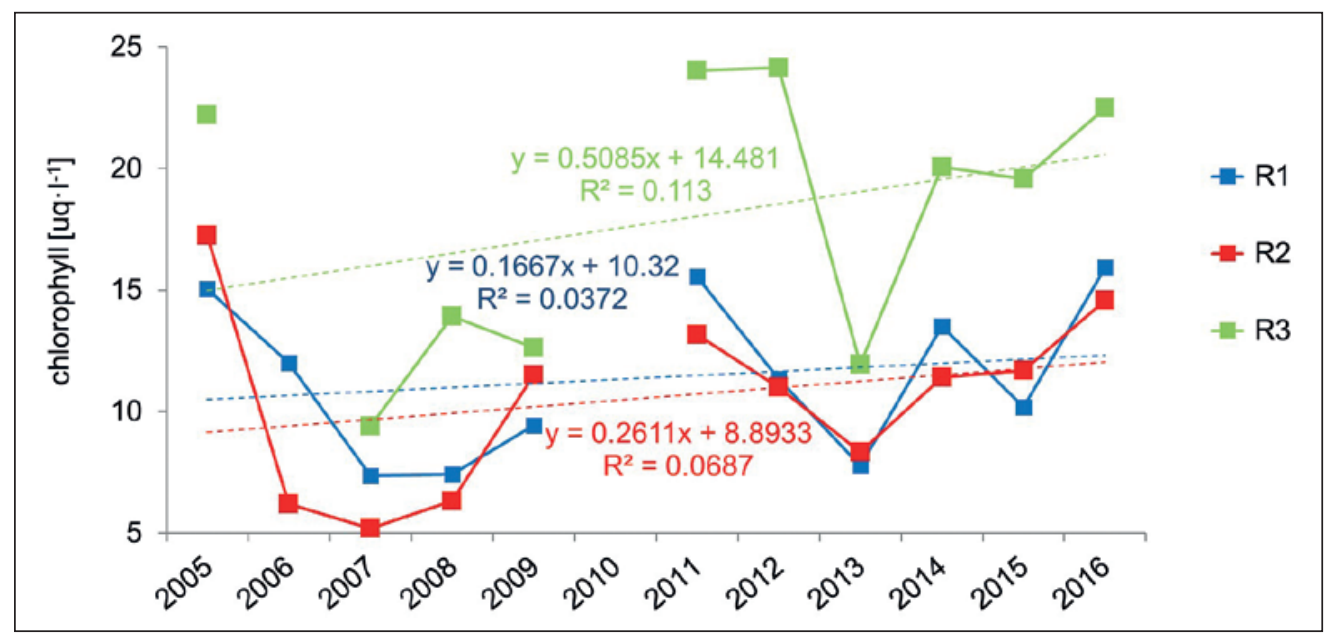

Fig. 8 Average chlorophyll- $\alpha$ concentration (2005-2016) at selected profiles in the Slapy Reservoir.

decreasing concentrations in the direction of the reservoir.

The numerical trophic index values for the Mastník bay are given in Table 7. All indices clearly show the hypertrophic conditions of the bay. Hypertrophic refers to high levels of biological productivity characterized by frequent and severe algal blooms and low water transparency. The average CTSI value for the bay was 65.66 , indicating that the bay is at a hypertrophic level (Table 3) and ranged between 53.6 (eutrophic) at station S2 to 79.13 (hypertrophic) at S6. The average TLI value was 6.04 and varied from 5.2 (supertrophic) to 6.96 (hypertrophic).

\subsubsection{Effect of nutrience of the Mastník bay on the Slapy Reservoir water quality}

It is obvious from the results, that eutrophication problems in the summer months are more intense in the bay than in the reservoir. Based on data from 2015 and 2016 for profiles (R1, R2) located on free water surface in the Slapy Reservoir, the difference in concentrations of parameters during the observed period is marginal (Table 8). Station R3 is very similar to R1, with the only differences concerning the chlorophyll concentrations, which are higher in R3 (Tab. 8). This fact has no impact on the profile $\mathrm{R} 2$, which is located just behind the mouth of the Mastník stream into the Vltava river. For example, in 2016 average chlorophyll concentrations in stations R3, R1 and R2 were $22.05 \mu \mathrm{g} \mathrm{l}^{-1}, 15.9 \mu \mathrm{g} \mathrm{l}^{-1}$ and $14.6 \mu \mathrm{g} \mathrm{l}^{-1}$ respectively.

Development of average chlorophyll concentration in mixed samples from Slapy sampling location during the growing season (May-October) is shown in Figure 8. The diagram shows that average concentrations increase over the years at each profile. The linear trend has a slight positive slope. This increase is also confirmed by the value of the MKT. However, except for July on the R1 and R3 profiles, this trend is not significant at the alpha $=0.1$ level (Tab. 9). There is also a considerable variation between the years.

The numerical values of the trophic index for the Slapy Reservoir are given in Table 10. All indices show different conditions. The CTSI value was 52.43 , indicating that the reservoir is at a eutrophic level (Table 3), meaning a water body with high biological

Tab. 8 Water quality of sampling location at the Slapy Reservoir (mixed samples for growing season 2015-2016).

\begin{tabular}{|c|c|c|c|c|c|c|c|c|c|}
\hline \multirow{2}{*}{$\begin{array}{l}\text { Station } \\
\text { Component/index }\end{array}$} & \multicolumn{3}{|c|}{$\mathbf{R} 1$} & \multicolumn{3}{|c|}{$\mathbf{R 2}$} & \multicolumn{3}{|c|}{ R3 } \\
\hline & Mean & Median & $C(90)$ & Mean & Median & $C(90)$ & Mean & Median & $C(90)$ \\
\hline Water temperature $\left[{ }^{\circ} \mathrm{C}\right]$ & 17.22 & 18.00 & & 16.96 & 17.95 & & 17.25 & 17.95 & \\
\hline Dissolved oxygen [mg |-1] & 10.20 & 10.40 & 8.10 & 9.96 & 9.70 & 9.40 & 10.69 & 10.65 & 8.60 \\
\hline Saturation $\mathrm{O}_{2}[\%]$ & 105.27 & 109.00 & & 101.69 & 105.00 & & 110.51 & 112.50 & \\
\hline $\mathrm{TN}\left[\mathrm{mg} \mathrm{I}^{-1}\right]$ & 2.31 & 2.35 & 3.00 & 2.39 & 2.45 & 3.20 & 2.31 & 2.30 & 3.20 \\
\hline $\mathrm{N}-\mathrm{NH}_{4}{ }^{+}\left[\mathrm{mg} \mathrm{l}^{-1}\right]$ & 0.04 & 0.03 & 0.06 & 0.04 & 0.03 & 0.06 & 0.04 & 0.03 & 0.06 \\
\hline $\mathrm{N}-\mathrm{NO}_{3}{ }^{-}\left[\mathrm{mg} \mathrm{I}^{-1}\right]$ & 0.02 & 0.02 & 2.70 & 0.02 & 0.02 & 2.50 & 0.02 & 0.02 & 2.70 \\
\hline $\mathrm{N}-\mathrm{NO}^{2-}\left[\mathrm{mg} \mathrm{l}^{-1}\right]$ & 1.98 & 2.00 & 0.03 & 1.99 & 2.00 & 0.01 & 1.86 & 1.80 & 0.04 \\
\hline $\mathrm{TP}\left[\mathrm{mg} \mathrm{l}^{-1}\right]$ & 0.03 & 0.03 & 0.04 & 0.03 & 0.03 & 0.05 & 0.05 & 0.04 & 0.07 \\
\hline Chlorophyll- $\alpha\left[\mu \mathrm{g}^{-1}\right]$ & 13.05 & 8.05 & 35.00 & 13.13 & 7.40 & 40.00 & 21.03 & 20.50 & 50.00 \\
\hline $\mathrm{Fe}\left[\mathrm{mg} \mathrm{l}^{-1}\right]$ & 0.04 & 0.03 & 0.08 & 0.04 & 0.03 & 0.06 & 0.05 & 0.04 & 0.07 \\
\hline
\end{tabular}


Tab. 9 Trend analysis in time series using the MKT (2005-2016).

\begin{tabular}{|c|c|c|c|c|c|c|c|c|c|c|c|c|}
\hline \multirow{3}{*}{$\begin{array}{l}\text { Station } \\
\text { Period } \\
\text { Parameter }\end{array}$} & \multicolumn{6}{|c|}{$\mathbf{R} 1$} & \multicolumn{6}{|c|}{$\mathbf{R 2}$} \\
\hline & \multicolumn{2}{|c|}{$\begin{array}{l}\text { Average vegeta- } \\
\text { tion period }\end{array}$} & \multicolumn{2}{|c|}{ July } & \multicolumn{2}{|c|}{ August } & \multicolumn{2}{|c|}{$\begin{array}{l}\text { Average vegeta- } \\
\text { tion period }\end{array}$} & \multicolumn{2}{|c|}{ July } & \multicolumn{2}{|c|}{ August } \\
\hline & MKT & S. & MKT & S. & MKT & S. & MKT & S. & MKT & S. & MKT & S. \\
\hline Temperature $\left[{ }^{\circ} \mathrm{C}\right]$ & -1.17 & $x$ & 1.35 & $\mathrm{x}$ & 1.35 & $x$ & -0.62 & $x$ & 0.81 & $x$ & 0.00 & $x$ \\
\hline Dissolved oxygen [mg l-1] & 0.75 & $\mathrm{x}$ & 0.54 & $x$ & 0.81 & $x$ & 0.07 & $x$ & 0.54 & $x$ & 0.45 & $x$ \\
\hline $\mathrm{N}-\mathrm{NH} 4\left[\mathrm{mg} \mathrm{l}^{-1}\right]$ & 1.44 & $x$ & 1.34 & $x$ & 1.04 & $x$ & 0.21 & $x$ & -1.39 & $x$ & 1.18 & $x$ \\
\hline $\mathrm{TP}\left[\mathrm{mg} \mathrm{l}^{-1}\right]$ & -0.48 & $x$ & 0.54 & $x$ & 0.00 & $x$ & -0.62 & $x$ & 0.09 & $x$ & 0.18 & $x$ \\
\hline Chl- $\alpha\left[\mu \mathrm{g} \mathrm{I}^{-1}\right]$ & 0.89 & $x$ & 2.60 & YES & 1.35 & $x$ & 1.17 & $x$ & 0.99 & $x$ & 1.25 & $x$ \\
\hline Station & \multicolumn{6}{|c|}{ R3 } & & & & & & \\
\hline Period & \multicolumn{2}{|c|}{$\begin{array}{l}\text { Average vegeta- } \\
\text { tion period }\end{array}$} & \multicolumn{2}{|c|}{ July } & \multicolumn{2}{|c|}{ August } & & & & & & \\
\hline Parameter & MKT & S. & MKT & S. & MKT & S. & & & & & & \\
\hline Temperature $\left[{ }^{\circ} \mathrm{C}\right]$ & -1.30 & $x$ & 1.35 & $x$ & 0.36 & $x$ & & & & & & \\
\hline Dissolved oxygen $\left[\mathrm{mg} \mathrm{l}^{-1}\right]$ & 0.89 & $x$ & 0.00 & $x$ & -0.63 & $x$ & & & & & & \\
\hline $\mathrm{N}-\mathrm{NH} 4\left[\mathrm{mg} \mathrm{l}^{-1}\right]$ & 1.43 & $x$ & -0.70 & $x$ & 0.35 & $x$ & & & & & & \\
\hline $\mathrm{TP}\left[\mathrm{mg} \mathrm{l}^{-1}\right]$ & 1.43 & $x$ & -0.20 & $x$ & 0.99 & $x$ & & & & & & \\
\hline Chl- $\alpha\left[\mu \mathrm{g} \mathrm{I}^{-1}\right]$ & 1.03 & $x$ & 1.79 & YES & 0.45 & $x$ & & & & & & \\
\hline
\end{tabular}

productivity, that can support an abundance of aquatic plants. The average value of TLI was 5.14, indicating a supertrophic water body.

To assess longitudinal changes in concentrations of observed parameters in two vertical profiles (R1, R2) at the Slapy Reservoir and for the effect of the Mastník catchment on reservoir water quality, diagrams of average concentrations of observed parameters (2005-2016) with depth interval of 5 meters were used (Figure 9). Diagrams show identical changes of average concentrations also in vertical profile. TP and $\mathrm{NNO}_{3}{ }^{-}$concentrations show minor differences.

These data confirm the negligible effect of the Mastník stream and dominance of internal water quality development in the bay. By the wide mouth of Mastník bay, water masses mix only minimally due to low velocities. In summer months, under mean hydrological conditions, the Slapy reservoir water mass behaves as a "dam", which retains the hypertrophic waters of the Mastník stream in its bay. During summer eutrophication development proceeds intensively (Mrkva 2018).

The average water retention time in the Slapy Reservoir is 36 days, while the retention time in Mastník bay is 55 days. However, the retention time can vary greatly depending on the inflow. For example, in the summer of 2018, the water level on the M1 profile was below $90 \mathrm{~cm}$ several times. This water level means the drought at this location (Czech Hydrometeorological Institute). This level corresponds to a discharge of $0.06 \mathrm{~m}^{3} \mathrm{~s}^{-1}$. The average inflow in 2018 in the growing season was only $0.15 \mathrm{~m}^{3} \mathrm{~s}^{-1}$, which is a very low value compared to the long-term average discharge $\left(1.26 \mathrm{~m}^{3} \mathrm{~s}^{-1}\right)$. Under low flow conditions, retention period would be 454 days.

\section{Discussion}

The physical and chemical indicators investigated in this research have been used to assess the water quality of the Mastník bay and to assess its impact on the Slapy Reservoir, a reservoir on the Vltava River in Czechia. Poor water quality of the Mastník catchment manifests itself in the Mastník bay. Significant phytoplankton development has been observed during the growing season (Mrkva 2018) Due to the low water velocity in the bay the water exchange with the Vltava

Tab. 10 Trophic index for the Slapy Reservoir in 2016.

\begin{tabular}{|c|c|c|c|c|c|c|c|c|}
\hline \multirow{3}{*}{$\begin{array}{l}\text { Station } \\
\text { R1 }\end{array}$} & \multicolumn{4}{|c|}{ Components average value } & \multicolumn{4}{|c|}{ Trophic index } \\
\hline & \multirow{2}{*}{$\begin{array}{c}\text { SD [m] } \\
2.17\end{array}$} & \multirow{2}{*}{$\begin{array}{c}\text { TN [mg l-1] } \\
2.47\end{array}$} & \multirow{2}{*}{$\begin{array}{c}\mathrm{TP}\left[\mathrm{mg} \mathrm{l}^{-1}\right] \\
0.03\end{array}$} & \multirow{2}{*}{$\begin{array}{c}C h l-\alpha\left[\mu \mathrm{I} \mathrm{I}^{-1}\right] \\
15.91\end{array}$} & \multicolumn{2}{|c|}{ CTSI } & \multicolumn{2}{|c|}{$\overline{\text { TLI }}$} \\
\hline & & & & & 51.86 & eutrophic & 5.09 & supertrophic \\
\hline R2 & 2.24 & 2.54 & 0.02 & 14.50 & 49.80 & mesotrophic & 4.96 & eutrophic \\
\hline R3 & 1.87 & 2.51 & 0.05 & 22.50 & 55.63 & eutrophic & 5.37 & supertrophic \\
\hline \multicolumn{5}{|c|}{ Overall total trophic index } & 52.43 & eutrophic & 5.14 & supertrophic \\
\hline
\end{tabular}




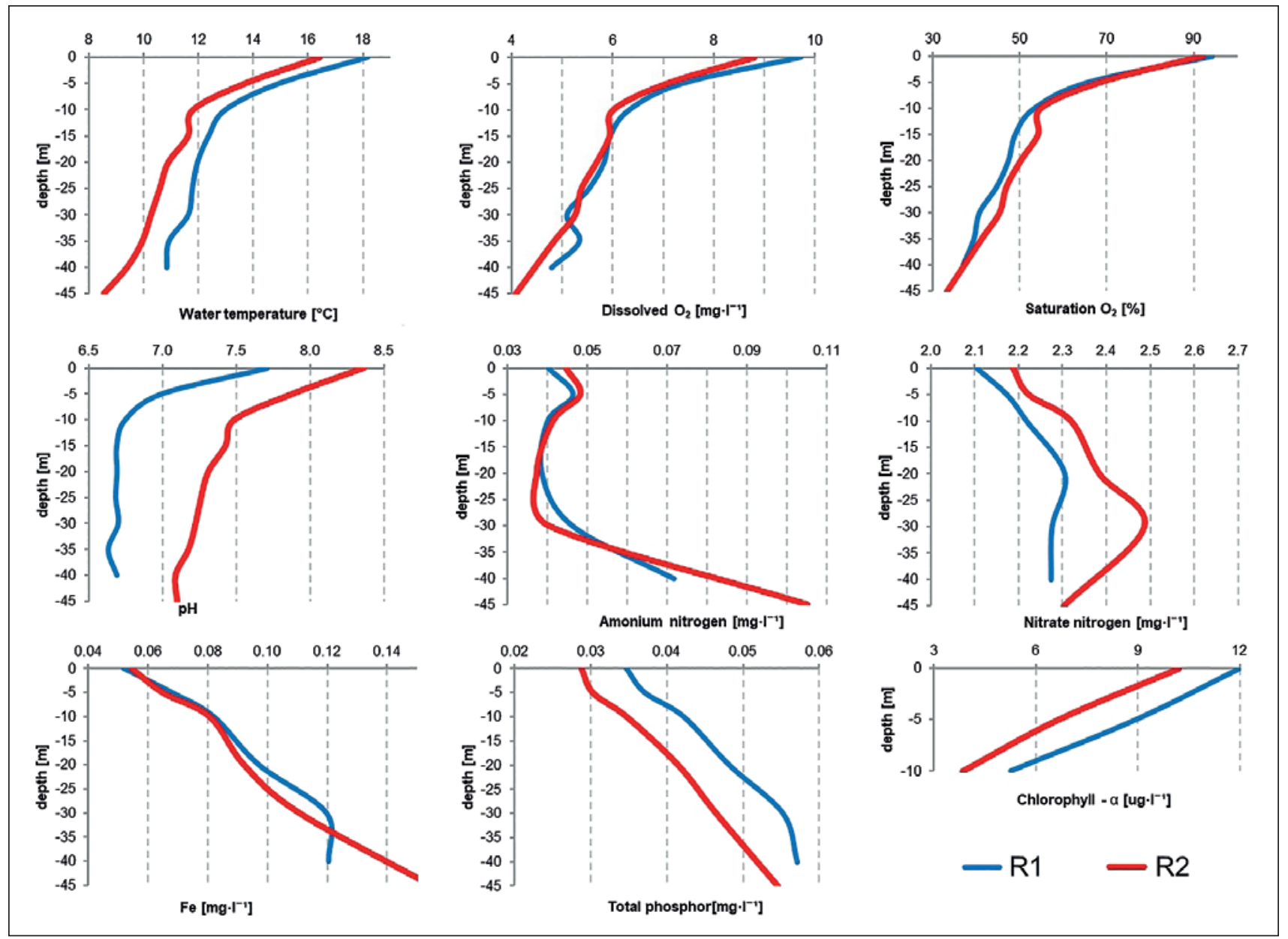

Fig. 9 Comparison of stratification of different parameters at R1 and R2 locations of the Slapy Reservoir (average from 2005 to 2016).

river is limited, resulting in favourable conditions for eutrophication.

Temperature is an important factor to consider when assessing water quality. Temperature can alter the physical and chemical parameters of surface waters. It affects the metabolic rate and biological activity of aquatic organisms, the concentration of DO in water and the toxicity of compounds (Wetzel 2001). Photosynthesis and thus the reproduction of phytoplankton accelerates by heat until a certain optimum. In July and August between 2016 and 2018 the surface water temperature in the Bay ranged from $21^{\circ} \mathrm{C}$ to $25^{\circ} \mathrm{C}$. These summer surface water temperatures are similar to the average water temperatures of lakes in much warmer latitudes, such as Lake Hawassa, Ethiopia, where the average water temperature is $21.23{ }^{\circ} \mathrm{C}$ (Worako 2015), Lake Timshah in the Suez Strait, which averages $22{ }^{\circ} \mathrm{C}$ (El-Serehy et al. 2018) and Xinlicheng Reservoir with an average summer value of $22.6^{\circ} \mathrm{C}$ (Guo et al. 2018). Minimum temperatures were found in May and October, falling down to $5{ }^{\circ} \mathrm{C}$. In the summer months, significant temperature stratification was confirmed with temperature difference in the water column reaching $12^{\circ} \mathrm{C}$.

In the case of large and rapid death of phytoplankton, there may be a significant reduction in $\mathrm{O}_{2}$ concentration at greater depths due to the consumption of $\mathrm{O}_{2}$ during microbial decomposition of dead matter, often leading to low oxygen zones near the bottom. This may be the reason for the observed vertical differences of oxygen in the Mastník bay. Waters with lower $\mathrm{O}_{2}$ saturation are usually below the thermocline, where the oxygen content is not affected by surface waves and photosynthesis. In contrast, supersaturation can often occur near the water surface due to high levels of photosynthesis or a significant change in temperature (Weitkamp, Katz 1980). This condition becomes evident in summer (Figure 5). At a depth of $2 \mathrm{~m}$, both the highest phytoplankton concentration and the highest $\mathrm{O}_{2}$ saturation occur, while below the thermocline at water depth of more than $5 \mathrm{~m}$ the saturation decreases to $50 \%$. The measured oxygen saturation is also affected by the time of sampling, because in summer a strong change in temperature between day and night occurs, while at the same time change in radiation effect the photosynthetic activity of the algae. The largest production of oxygen by phytoplankton is in the morning. Overall, the measured data show that highest $\mathrm{O}_{2}$ concentrations and oxygen saturations are observed in stations S7, S6 and S5. This is attributed to a nearby tributary to the bay, which provides nutrients for the growth of phytoplankton. 
This view is supported by data on phosphorus and chlorophyll concentrations in this part of the bay. An average concentration of DO for the whole monitored period was $8.4 \mathrm{mg} \mathrm{I}^{-1}$. In different reservoirs, for example in the Xinlicheng Reservoir in China, where the average concentration was $8.45 \mathrm{mg} \mathrm{I}^{-1}$. The summer average in this reservoir was $1 \mathrm{mg} \mathrm{I}^{-1}$ lower than average of the Mastnik bay (Guo et al. 2018). In the Feitsui Reservoir in Taiwan, which is located in an area with a subtropical oceanic climate, its mean DO value $7.14 \mathrm{mg} \mathrm{I}^{-1}$ (Chen 2014).

According to both indices of the trophic state, the state of the Mastník bay is hypertrophic. The profiles on the Slapy Reservoir show a better classification concerning the degree of trophy, with CTSI evaluating it as eutrophic and TLI evaluating it as supertrophic. It should be noted that the overall condition of the bay is distorted by the profiles at the top of the bay. In the case of stations S2 and S3, the results are comparable to the Slapy Reservoir itself. Eutrophication is more pronounced in upper part of the Mastník bay due to its shallowness and the longer water residence time might also support eutrophication. The most important parameter affecting the evaluation of the trophic state of this bay appears to be chlorophyll, in contrast to the results of other investigations. For example, in the case of Lake Hawassa in Ethiopia, the TSI is 73, but the average chlorophyll concentration is $28 \mu \mathrm{g} \mathrm{I}^{-1}$, as compared to the average of the bay in this study $\left(103 \mu \mathrm{g} \mathrm{I}^{-1}\right)$. However, Hawassa has significantly higher concentrations of TP (Worako 2015). Xinlicheng Reservoir has been reported to have an average TSI value of 50.65, which indicates that the reservoir is generally in a eutrophic state (Guo et al. 2018). Lake Timsah has a TSI of 60 and a TLI of 5.2 , and significantly lower concentrations of $\mathrm{Chl}-\alpha$ $\left(20 \mu \mathrm{g} \mathrm{I}^{-1}\right)$. However, it has also higher concentrations of TP $\left(0.48 \mathrm{mg} \mathrm{I}^{-1}\right)$ and TN $\left(7.2 \mathrm{mg} \mathrm{I}^{-1}\right)$ (El-Serehy et al. 2018) when compared to average concentrations (TP: $0.125 \mathrm{mg} \mathrm{I}^{-1}$; TN: $2.09 \mathrm{mg} \mathrm{I}^{-1}$ ) of the Mastník bay. The Feitsui Reservior has average TP concentration $0.21 \mathrm{mg} \mathrm{I}^{-1}$ and CTSI is in the range of mesotrophic and eutrophic (Chen 2014). In New Zealand (NZ) lakes TLI values are significantly lower than values in the Mastník bay, averaging about 4.0, which ranks the lakes between mesotrophic and eutrophic. In addition to the significant difference in $\mathrm{Chl}-\alpha$ concentrations between the Mastník bay and NZ lakes, there is also a large difference in transparency, which averages $5 \mathrm{~m}$ are in NZ lakes (Burns et al. 2005) when compared to the Mastník bay average of $1.15 \mathrm{~m}$. Reservoirs on the Paranapanema River in Brazil showed similar indices as the Mastník bay, although different trophic indices have used for reservoirs in tropical and subtropical areas (Pomari et al. 2018). Assessment of the trophic condition of a lake are often directly linked to water quality. However, in some cases, this is very inappropriate, since there are naturally eutrophic water bodies. It is therefore necessary to consider this information before directly relating trophic status in direct to water quality (Parparov 2010). Naturally eutrophication is not related with the Mastník bay, where eutrophication is affected by human activity and the pollution of the Mastník stream is the result of human activities.

In the case of $\mathrm{TP}$, a slight predominance of point sources of pollution is observed in the Mastník river basin (Mrkva 2018). The concentration of TP discharged into the Mastník recipient does not change significantly during the year. Thus, the benefit of TP from the river basin is not as crucial as its supply of TP in sediments that form throughout the season and especially at high flows, when the capabilities of WWTPs are reduced. In a relatively shallow bay, TP sediment is more readily available phytoplankton than in the deep reservoir itself. But the results of some studies demonstrate that sediment-derived $\mathrm{P}$ stimulates phytoplankton growth, but that its effect on phytoplankton dynamics is modulated by other factors, such as light (Cymbola et al. 2008).

\section{Conclusion}

High water residence times in the Mastnik Bay favour algal growth, especially during the growing season. Water quality parameters, which involved nutrients and oxygen concentrations, water temperature and phytoplankton biomass in the Mastník bay was investigated over three growing seasons (2016-2018) to describe the trophic state and water quality of the Mastník bay and ascertain its effect on the Slapy Reservoir. Based on trophic indices, the bay can be classified as hypertrophic while the Slapy Reservoir itself is eutrophic. Total phosphorus concentrations in the bay are still high, even though the supply of phosphorus from the Mastník catchment area is decreasing. An increase of eutrophication and thus chlorophyll concentration can also be associated with increasing surface water temperatures and stronger thermal stratification, or by releasing TP from the sediment. However, the effect of the Mastník catchment on the concentration of the monitored substances of the main water body of the reservoir could not been proven.

Nevertheless, a small change in the quality of surface water in a river basin can cause a change in the ecological characteristics of the whole stream and its surroundings. In the case of the Mastník bay, it is necessary to reduce phosphorus inputs into the reservoir to prevent eutrophication. Improvement of WWTP efficiency and reduction of diffuse sources seem to be suitable measures. In the coming decades, water flows could be more affected by changing climate, as already observed in 2018. Rising air temperatures and changes in precipitation may result in deterioration of surface water quality despite all measures and investments made so far. It is necessary to continue devoting attention to this issue. 


\section{Acknowledgements}

This article is supported by the Grant Agency of Charles University (project No. 476318), from specific university research (SVV260573) and by Charles University Research Centre program (UNCE/HUM/018).

\section{References}

Burns, N., McIntosh, J., Scholes, P. (2005): Strategies for managing the lakes of the Rotorua district, New Zealand. Lake and Reservoir Management 21(1), 61-72, https:// doi.org/10.1080/07438140509354413.

Carlson, R. E. (1977): A Trophic State Index for Lakes. Limnology and Oceanography 22(2), 361-369, https:// doi.org/10.4319/lo.1977.22.2.0361.

Chen, W. B., Liu, W. C. (2014): Artificial neural network modeling of dissolved oxygen in reservoir. Environmental Monitoring Assessment 186, 1203-1217, https://doi.org/10.1007/s10661-013-3450-6.

Cymbola, J., Ogdahl, M., Steinman, S. D. (2008): Phytoplankton response to light and internal phosphorus loading from sediment release. Freshwater Biology 53, 2530-2542, https://doi.org/10.1111 /j.1365-2427.2008.02079.x.

ČSN 757221 (2017): Water quality. Classification of surface water quality. Czech Office for Standards, Meteorology and Testing, Prague.

El-Serehy, H. A., Abdallah, H. S., Al-Misned, F. A., Al-Farraj, S. A., Al-Rasheid, K. A. (2018): Assessing water quality and classifying trophic status for scientifically based managing the water resources of the Lake Timsah, the lake with salinity stratification along the Suez Canal. Saudi Journal of Biological Sciences 25(7), 1247-1256, https://doi.org/10.1016/j.sjbs.2018.05.022.

Government of the Czech Republic (2018): National Research and Innovation Strategy for the Smart Specialization of the Czech Republic (National RIS3 Strategy) 2014-2020 (actualization 2018), p. 292.

Guo, J., Zhang, C., Zheng, G., Xue, J., Zhang, L. (2018): The establishment of season-speci fi c eutrophication assessment standards for a water-supply reservoir located in Northeast China based on chlorophyll-a levels. Ecological Indicators 85, 11-20, https://doi.org 10.1016/j.ecolind.2017.09.056.

Hamilton, D., Parparov, A. (2010): Comparative assessment of water quality with the trophic level index and the delphi method in lakes rotoiti and rotorua, New Zealand. Water Quality Research Journal of Canada 45(4), 479-489, https://doi.org/10.2166/wqrj.2010.046.

Heo, J. H., Kho, Y. W., Shin, H., Kim, S., Kim, T. (2008): Regression equations of probability plot correlation coefficient test statistics from several probability distributions. Journal of Hydrology 355(1-4), 1-15, https://doi.org/10.1016/j.jhydrol.2008.01.027.

Jarvie, H. P., Neal, C., Withers, P. J. A. (2006): Sewage-effluent phosphorus: A greater risk to river eutrophication than agricultural phosphorus? Science of The Total Environment 360(1-3), 246-253, https://doi.org /10.1016/j.scitotenv.2005.08.038.

Mrkva, L., Janský, B. (2018): Surface water quality in the Mastnik stream catchment area: The situation in the
Czech countryside. Geografie-Sbornik 123(4), 479-505, https://doi.org/10.37040/geografie2018123040479.

Novický, O., Kašpárek, L., Peláková, M. (2006): Climate change impacts and responses in the Czech Republic and Europe. IAHS-AISH publication 308, 418-423.

Park, Y., Cho, K. H., Cha, J. P. S. M., Kim, J. H. (2015): Development of early-warning protocol for predicting chlorophyll-a concentration using machine learning models in freshwater and estuarine reservoirs, Korea. Science of the Total Environment 502, 31-41, https:// doi.org/10.1016/j.scitotenv.2014.09.005.

Parparov, A. (2010): Water Quality Assessment, Trophic Classification and Water Resources Management. Journal of Water Resource and Protection 2(10), -915, https://doi.org/10.4236/jwarp.2010 .210108

Pomari, J., Kane, D. D., Nogueira, M. G. (2018): Application of multiple-use indices to assess reservoirs water quality and the use of plankton community data for biomonitoring purposes. International Journal of Hydrology 2(2), 167-179, https://doi.org/10.15406 /ijh.2018.02.00065.

Prasad, A. G. D. et al. (2012): Carlson's Trophic State Index for the assessment of trophic status of two Lakes in Mandya district. Advances in Applied Science Research 3(5), 2992-2996.

Procházková. L., Blažka. P., Kopáček. J. (1996): Impact of diffuse pollution on water quality of the Vltava River (Slapy Reservoir), Czech Republic. Water Science and Technology 33(4-5), 145-152, https://doi. /10.1016/0273-1223(96)00224-7.

Rosa, G. C., Michelle, S. (2007): Trophic status evaluation for 154 lakes in Quebec: canada:monitoring and recommendations. Water Quality Research Journal 42(4), 252-268, https://doi.org/10.2166/wqrj.2007 .028 .

Smith, V. H. (2003): Eutrophication of Freshwater and Coastal Marine Ecosystems; A Global Problem. Environmental Science and Pollution Research 10, 126-139, https://doi.org/10.1065/espr2002.12.142.

Taylor, S. D., He, Y., Hiscock, K. M. (2016): Modelling the impacts of agricultural management practices on river water quality in Eastern England. Journal of Environmental Management 180, 147-163, https:// doi.org/10.1016/j.jenvman.2016.05.002.

Viney, N. R., Bates, B. C., Charles, S. P., Webster, I. T., Bormans, M. (2007): Modelling adaptive management strategies for coping with the impacts of climate variability and change on riverine algal blooms. Global Change Biology 13(11), 2453-2465, https://doi.org /10.1111/j.1365-2486.2007.01443.x.

Weitkamp, D. E., Katz, M. (1980): A Review of Dissolved Gas Supersaturation Literature, Transactions of the American Fisheries Society 109 (6), 659-702, https:// doi.org/10.1577/1548-8659(1980)109<659:ARODGS> 2.0.CO;2.

Wetzel, R. G. (2001): Limnology: Lake and River Ecosystems (3rd ed.). San Diego, CA: Academic Press, 1006, https://doi.org/10.1016/C2009-0-02112-6.

Worako, A. W. (2015): Physicochemical and biological water quality assessment of lake Hawassa for multiple designated water uses. Journal of Urban and Environmental Engineering 9(2), 146-157, https:// doi.org/10.4090/juee.2015.v9n2.146157. 